\title{
Analysis of The Four Pillars of Tourism Development Planning in The Tourism Areas of Kretek, Bantul, Yogyakarta, Indonesia
}

\author{
Ani Wijayanti \\ Hospitality Department \\ BSI Tourism, Academy \\ Yogyakart, Indonesia \\ ani.awi@bsi.ac.id
}

\author{
Ike Janita Dewi \\ Manajement Departement \\ Sanata Dharma University \\ Yogyakarta, Indonesia \\ ikejanitadewi@yahoo.com
}

\begin{abstract}
Tourism sector has played an important role in economic development in Kretek district of Bantul regency. Tourism is main life style of Kretek People. Result of current research indicated that Kretek district has many superior destinations that have not been worked maximally. Its tourism product was stagnant and tourism attraction decreased. The condition requires government intervention as one of stakeholders particularly in determining policy and capital. Product diversification and revitalization should be done in the industry to improve quality and quantity of tourism product. The product is offered by Kretek destination as potential one. It is marketed by brand strengthening, promotion and partnership with other parties.
\end{abstract}

Keywords-tourism; development; destination; marketing; industry; institution.

\section{BACKGROUND AND STATEMENT OF THE PROBLEM}

Tourism sector has played an important role in economic development of a region. The increasingly high levels of development and prosperity in community have actually made tourism as a fundamental part of the human needs or lifestyles and mobilized millions of people to get acquainted with the nature and culture in other parts of the world. Such movement of millions of people has in turn moved the interlinked economic chain into a variety of service industries, which make an important contribution to the economy as well as the improvement of economic welfare at local community level.

There are tourism potentials in Yogyakarta Special Territory including natural, cultural and artificial tourism. Various performing arts developed well. Traditional and modern performing arts and modification of both may be found in people life. Cultural heritage in physical and non physical form and ritual are still kept and have strong root in the community. The rituals are done routinely by people and it is tourism potential that is appropriate for tourism agenda. In DIY renaissance strategy, tourism is the second strategic priority to develop in creating the province to reach vision of Yogyakarta Special Territory in 2025 as educational center, cultural center and tourism destination in Southeast Asia.

Bantul Regency is one of the regencies in Special Region of Yogyakarta, consisting of three subdistricts, i.e. Kretek Subdistrict, Sanden Subdistrict, and Srandakan Subdistrict. Bantul Regency has a strategic position in the constellation of tourism because the location is adjacent to urban centers than other regencies, and it has various leading tourism destinations to visit. Along the southern side, there is a coastal landscape called as the coastal areas of the South Coast with its potential marines and sandbank areas as one of the specific natural phenomenon. Kretek Subdistrict has the leading destination of natural tourism, artificial tourism, cultural tourism, special tourism, educational tourism, and tourist villages.

Several strategic reasons for the development of tourism areas of the South Coast in Bantul Regency are as follows: (1) Balance in the distribution of tourism in Special Region of Yogyakarta and Bantul Regency, (2) The great potentials of the South Coast as a tourism growth center in Bantul Regency and Special Region of Yogyakarta, (3) The strategic issues of tourism in Bantul Regency, including (a) the stagnation of tourism products so that it is necessary to create new tourism attractions and arrange the tourism destinations that have not operated optimally, (b) the reduced prestige of beaches in Bantul Regency, (c) the emergence of many environmental pollutions, unregulated building structures, the land use conflicts of interest, synergy in development program, and the strategic location that is close to the city and easily accessible, (4) The availability of tourism facilities, tourism growth embryos, and popular new tourism attractions (Parangtritis Beach, Depok Beach, Baru Beach, and so on), and (5) The great potentials to grow the diversity of local community tourism products (craft and culinary industries).

\section{LITERATURE REVIEW}

\section{A. Tourism Development}

Prospect of integrated and sustainable development has close association with tourism. Although it is not directly intended to tourism it gives indirectly contribution to tourism development. For example, accessibility improvement, environmental conservation, cultural and natural tourism conservation, pollution reduction, increase in quality and availability of natural resource affect greatly on increase in tourism sector performance. Integration of tourism sectors should be done through public and private partnership. Tourism should work to integrate natural and cultural tourism, 
environmental protection, accessibility and development with the most appropriate method [1].

\section{B. Tourism Destination}

Tourism destination is a consolidation between products and experiences that affecting tourist to do traveling [2]. Currently there is shift in tourism goal from mass tourism to alternative tourism. The change demands management to be more creative in managing tourism and can create tourist friendly destination. Environment and tourism has close association. Tourist destination environment include socio cultural, resource, and heritage values that affect tourism growth in the area [3].

Tourist attraction will be main goal of tourist in visiting a destination. In general, tourist attraction is classified into two groups: natural tourism and artificial tourism. Natural tourism includes natural view, mountain, waterfall, beach and wildlife. Meanwhile, artificial tourism includes history, civilization and culture [4]. Cultural tourism may be seen from two perspectives: tourist and local community. Tourist perception is influenced by image given by host, as tour provider [5].

Tourist attraction having uniqueness characteristic can be important variable for competitive destination. Some tourist characteristics are battle field, historical heritage, and natural view that give competitive advantage, although it is expensive. Ecotourism is an alternative to be able to provide competitive advantage. Ecotourism as one of natural tourisms has objective of conservation and economic and rural development. Ecotourism also offer education and new experience for tourist. It should be developed and managed by considering protection and environmental conservation [6]. In addition, building destination image is very important for tourism marketing in context of increasingly globalized tourism competition [7].

\section{Tourism Marketing}

Advertisement is very important factors in tourism industry, because tourist product and service cannot be brought or moved. Information delivered through advertisement is means to promote characteristic and feature of a destination. In early step, advertisement is means to fill gap between supply and demand in tourism industry. Currently, marketing have used big scale adv to draw more tourist. Brochure, TV and internet advertisement, and film are example of increasingly strong effort to introduce tourist attraction of a country [4].

\section{Tourism Industry}

Tourism is a series of activities, interaction and communication between tourist and destination as host that have responsible to prepare all tourist need, including accommodation, transportation, food, entertainment and security. Tourist is people that want to spent their time at other city, province or state for recreation, business, study and other objectives [4]. In Iran, tourist industry is an important substitution for oil, because it created employment and gave high foreign exchange [4]. Tourism is acknowledged as intensive industry resource and has responsibility in realizing sustainable condition in local and global scale. Sustainable tourism is main objective in developing integrated environmental tourisms. However, the research indicated that sustainability is complex concept and require comprehensive critical analysis [8], [9].

\section{E. Tourism Institution}

In a management process, it is necessary involvement of institution and human resource that include all tourist managing institutions including supporting human resources related to tourist management in a destination. Tourism management institutions consist of government, private and community [10]. Role of tourism institution in managing a tourist destination is required from planning to monitoring.

Tourism organization has function of coordination among institutions, monitoring various tourist activities, planning and applying tourism promotion and monitoring price policy [11]. In general tourism organization has responsibility in developing and guiding tourism. Government plays very strong role in promotion and systematic development of a tourism destination, monitoring and state policy without hampering private initiative. Increasingly sharp competition demand new policies in marketing, production and even price policy by authoritative government. Natural Involvement of government in tourism includes active and passive involvement. Active involvement is marked with government action in supporting tourism sector. Passive involvement occur when government do action that possible have implication for tourism, but it is not directly dedicated to support or affect tourisms development [12].

There are two categories of stakeholder: people that can affect decision and people that are influenced by decision taken [13]. There are some approaches to stakeholders such as stakeholder involvement depending on perspective of each stakeholder [14], while [15] suggest that stakeholder interaction is influenced by issue of certain policy. Local tourism administrator has responsibility in planning and management process [16]. In this matter, involvement of local people is very important in communicative and participative form for planning tourism area [17]. [18], [19], and [20] state that involvement of tourism stakeholders can increase people empowerment and increase tourism product. It emphasizes approach of stakeholders having normative and instrumental value

\section{RESEARCH DESIGN}

This study was conducted using a qualitative-descriptive method to determine the great potentials of tourism in Kretek Subdistrict Bantul Regency and the efforts of tourism development based on the four pillars of tourism. Informants in the study were selected using a snowball sampling technique where interviews were carried out with an initial key informant and followed by the next informant to obtain the data as complete as possible [21]. For the data validity, triangulation test was carried out based on various sources of 
information and all the data were analyzed through three stages: data reduction, display, and verification [22].

\section{RESULT AND DISCUSSION}

Kretek district is in south of Bantul capital, with 2,677 Ha area consisting of five villages (Donotirto, Parangtritis, Tirtomulyo, Tirtohargo, and Tirtosari). The total area is 2,677 hectares, there were 7,763 household with the population density of 1,152 people $/ \mathrm{km}^{2}$ where $55.8 \%$ of the population working in the agricultural sector. The map of Kretek Subdistrict can be seen in Figure 1.

Fig 1. Map of Kretek Subdistrict

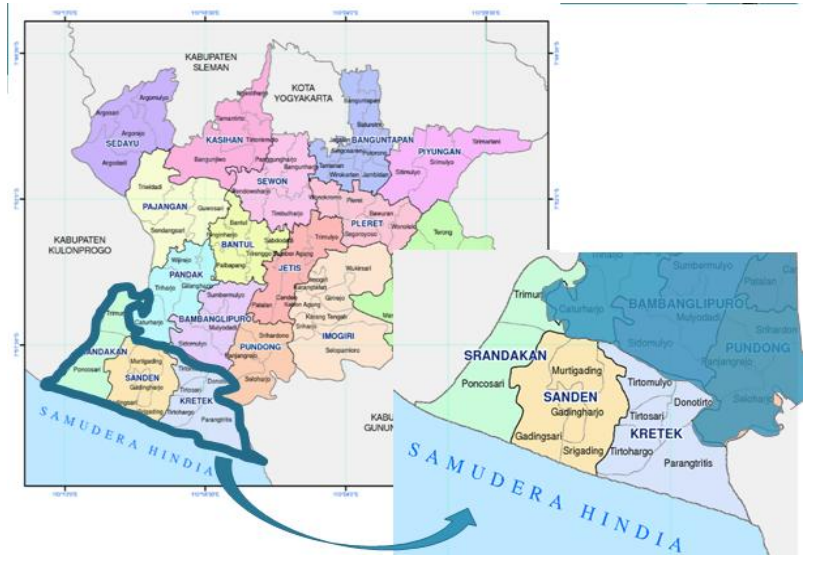

The potentials of tourism attraction in Kretek Subdistrict include natural and artificial tourism, educational tourism, cultural tourism, heritage, and village tourism. The natural and artificial tourism are such as (1) Parangtritis beach area with slightly slope beach, rocky hills, white sand coast, and limestone hill views on the northern coast, (2) Sand dunes, located on the western of Parangkusumo beach as a natural laboratory, (3) Depok beach, Depok lagoon, and Depok fish auction, (4) Parangwedang as mineral hot springs, (5) Parangkusumo beach, (6) Kergan Tourism Village, (7) Mangrove forests, (8) Coastal geospatial laboratory, and (9) Aeromodeling runway. Such tourism potentials can be seen in Figure 2.

Fig 2. Tourism Potensials of Kretek Subdstrict

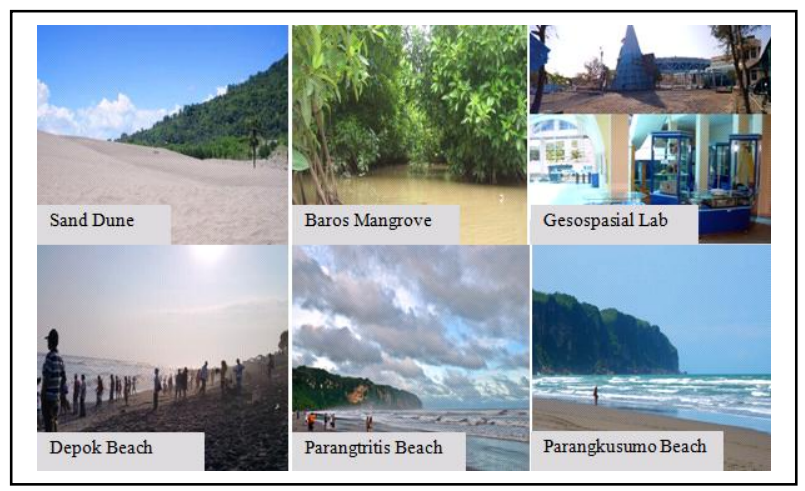

The cultural tourisms in the tourism area of Kretek Subdistrict are such as (1) Bekti pertiwi pisungsung jaladri, i.e. the embodiment of gratitude to God Almighty for windfall received, (2) Melasti ceremony, i.e. a tradition of the Hindu community to celebrate the Nyepi, (3) Labuhan Hondodento ceremony, i.e. one of the ceremonies organized in Parangkusumo by trah Hondodento to welcome Suro month, (4) Peh Cun ceremony celebration, i.e a tradition of Chinese community in order to commemorate the legend of an emperor who sacrificed for Chinese state, (5) Minabahari sea alms, and (6) Labuhan Keraton Ngayogyakarta. The cultural tourism attractions can be seen in Figure 3.

Fig 3. The Cultural Tourism Attractions

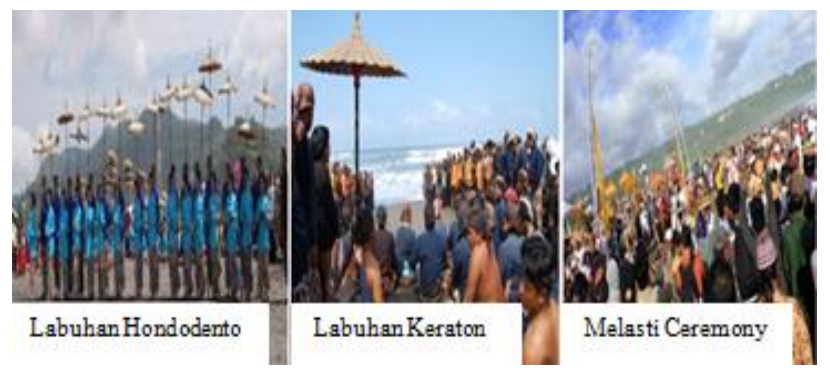

A. The Concept of Tourism Development through The Four Pillars of Tourism

The tourism development is oriented to improve the community's level of living, and revive and reinforce the values such as local history, local culture, and local economic production. According to Article 9 paragraph (5) of Law Number 10 of 2009 on Tourism, there are four main pillars of tourism development, i.e. tourism destination, tourism marketing, tourism industry, and tourism institutions and human resources. Considering the potentially large number of new tourism attractions in Kretek Subdistrict, it is important to implement the gradual tourism development program based on the four pillars as shown in Figure 4.

Fig 4. The Four Main Pillars of The Tourism Development

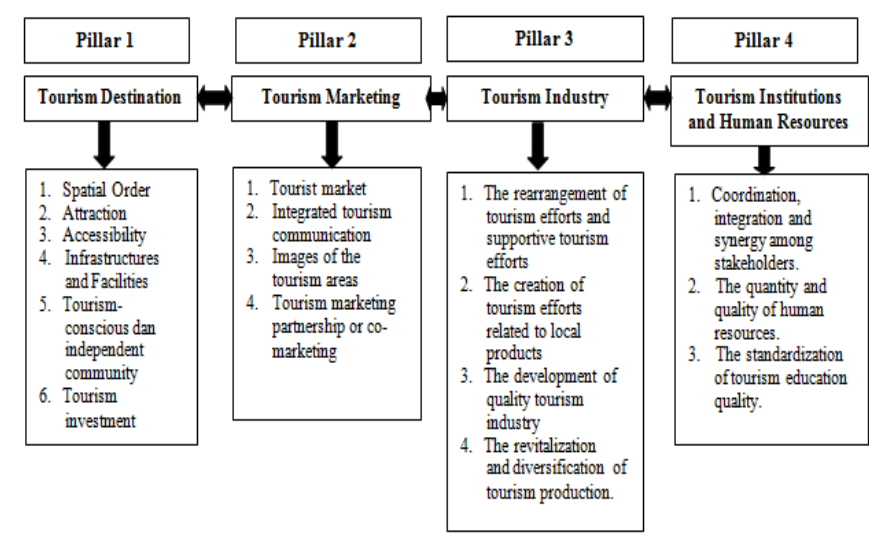

\section{B. Tourism Develpoment in Kretek District}

Tourist Destination aspect in Kretek District include spatial arrangement and zonation, attraction, accessibility, infrastructure and facility, community empowerment, and tourist investment. Development in attraction aspect may be done in some areas such as: 
1) Parangtritis beach. Development in Parangtritis beach may be done in some aspects: a) protection, development and usage of main zone including water resorption, coast boarder, pine forest and mangrove, b) revitalization of main attraction including coastal natural tourism, family recreation tourism, aero tourism, cultural tourism, religious tourism and culinary tourism

2) Parangkusumo sand dune is developed as geospatial conservation area and biosphere protective area

3) Depok beach may be developed as attraction empowerment in culinary tourism and aero tourism

4) Mangrove Baros is emphasized on revitalization and diversification and tourism product and attraction

Building accessibility is more emphasized on development of direct access and shuttle from hub, increasing connectivity quality, and transportation mode. Increasing connectivity quality was done by adding lighting, sign posting, development of tourist movement pattern with arranging visiting route, developing of tourist cart route between main area and development of water route of Laguna and Mangrove. Developing of infrastructure and facility is done on increasing tourism facility quality, communication facility, electricity network, water, accommodation, improvement of standard restaurant and garbage management.

People as main resource of a tourist destination are empowered to increase tourist awareness, community tourism business empowerment, and increase in quality and standardization of community tourism product. People empowerment was done through some programs. First, development and assistance of tourism conscious group, second development of tourism village based on developmental level and typology such as growing, developing and autonomous tourism villages. Third, productive business development was done through tourism product innovation. Fourth, improving tourism business service capability is through training.

In order to keep sustainability of a tourism business, investment is very important aspect because cost required in developing tourism is great. One of tourism investment done in Kretek destination area is aero tourism. Kretek destination area have auromodelling runway in east of fish market of Depok Beach. The runway is used when there is auromodelling event in DIY. In addition, investment may be done in educational destination such as mangrove, sand dune conservation, and culinary tourism.

\section{The Revitalization of Leading Tourism}

The sand dunes area is a major tourism attraction in the coastal areas of the South Beach as it is not only strategic for the development of natural and cultural tourism, but also for the development of educational tour. This tour is equipped with Geospatial laboratory well-known as Parangtritis Geomaritime Science Park. However, the laboratory building still seems too massive, closed and rigid, so that the revitalization of building should be carried out to change the visitors' mindset. The revitalization program can be implemented as follows: (1) The improvement of conservation program such as the protection, development and utilization of the core or middle part of the sand dunes area, (2) The revitalization of geospatial conservation and biosphere reserve area, i.e. sand dunes and geospatial laboratory, and (3) the designing of tourist travelling patterns in sand dunes tourism activities. The proposed tourist travelling patterns can be seen in Figure 5.

Fig 5. The Proposed Tourist Travelling Patterns

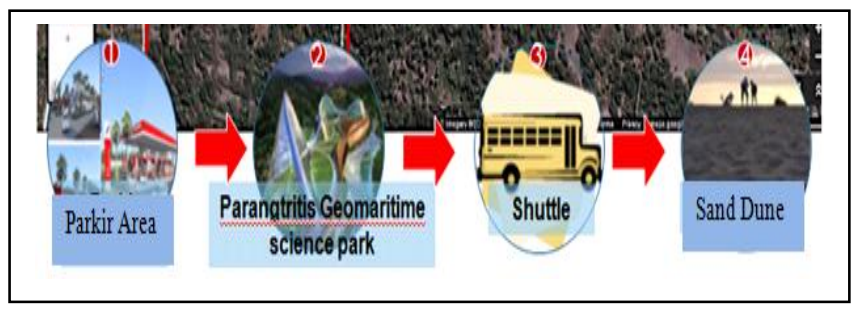

\section{Tourism Marketing in Kretek District}

Marketing is done with some ways such as creating tourism brand, promotion and partnership. Promotion may be done through above the line (ATL) and below the line (BLT). ATL marketing used printing media and electronic media, while BTL through event organizing intended directly to the market segment. Marketing partnership is form of marketing and promotion cooperation between its actors. Some marketing strategies done are documentation of sand dune phenomena in YouTube, sand boarding in sand dune, Perempuan Berkalung Sorban di Pantai Parangtritis" movie as promotion media and tourist product package for semi mass tourist and special interest tourist. In this case, Parangtritis beach and sand dune is strengthening object of master brand. Marketing partnership was done with travel agent, tour operator, airline, bank and other corporate.

\section{E. Tourism Industry in Kretek Tourism Area}

Building tourism area should be designed as such so it gives welfare contribution for people. Tourism industry is developed to increase investment, create employment, and increase people income. Various developing tourism industry are hotel, restaurant, souvenir, food and beverage and other services that has direct relation with tourism. Tourism industry development in Kretek was done by some ways such as arranging tourism business, development of quality tourism industry, and revitalization and diversification of tourism product.

Structuration of Kretek industry area was adjusted with industry need and spatial arrangement. Arrangement was done by some ways such as regulating business infrastructure and access according to industrial need, normalization of coast border, coastal border intention, conservation activity, water resorption, and establishment of integrated tourism industry through building and facilitation of display spaces for local product. Arrangement of tourism business area determines greatly development process of the area. Tourism industry development was done by doing course, training, and internship for local people to develop tourism service supporting industry. Culinary and souvenir business is developed by increasing capital aspect for lower to middle economic business. Dissemination of investment opportunity should be done to increase capital. To make easy activity in tourism industry, government may play role in license and 
incentive for investor relevant to develop tourism industry in Kretek area.

Diversification and revitalization of tourism product is one of important actions in developing tourism industry in Kretek destination area. Product diversification was one in culinary and handycraft sector. Diversification in culinary sector includes various types of processed sea product, mie lethek, bakpia, processing cassava to be various foods, tofu and tempe. Meanwhile, diversification in handcraft includes cloth batik and bamboo batik, handfan, plait, traditional toy, kuda kepang, various bamboo handicraft, various souvenir of pandanus leaf fiber, eceng gondok and pine fruit. Revitalization was done in cultural tourism aspect. Cultural tourism attraction such as jathilan, dances and child game are developed as tourism attraction that can give employment, and conserve cultural heritage.

\section{F. Tourism Institution in Kretek Tourism Area}

In implementing tourism management, it is necessary efficient and effective cooperation from stakeholders including central government, local government, private sector and society. Local people participation as driving factor is very important. Participative planning of tourism business is done through partnership scheme. Three policy directions that should be considered in institution and human resources are improvement of coordination integration and synergy between stakeholders in supporting good tourism governance, improvement in human resource quantity and quality in supporting creation of prima and competitive tourism product and service and standardization of tourism educational institution quality. As a media for coordinating stakeholder in Kretek tourism area, local tourism management agency was established consisting of pokdarwis, local public service agency, tourism village communication forum, and village owned business entity (BUMDES). Increase in human resource quantity and quality was done by some ways such as optimization of human resource competence through training, seminar, scholarship for further study and internship.

\section{CONCLUSION}

Kretek district is one of districts in Bantul regency having many tourism potential, but they are not managed well yet. Effort to develop them was done through four pillars, there are: destination, marketing, industry and institution. From destination aspect, development was done by using main zone and supporting zone. Marketing of Kretek tourism was done by strengthening tourism brand, promotion and partnership. Product diversification and revitalization was done as effort to develop tourism industry and to empower local people. Stakeholder involvement is required to increase quality and quantity of tourism product.

\section{References}

[1] C.Morar. "Tourism Development Based on European and National Funding Programs in the Bihor County's Disadvantaged Mining Areas". Vol. 14, pp. 99-108, 2012.

[2] A.Nazrin, A.Anuar, A.Ahmad, H.Jusoh, and M.Y.Hussain (2011). The Roles of Tourism System towards Development of Tourist Friendly Destination Concept", Asian Social Science, vol. 8, 2011.

[3] R.Joshi and P.Dhyani, Environmental Sustainability and Tourism Implications of Trend Synergies of Tourism in Sikkim Himalaya", Current Science, vol. 97, 2009.

[4] F.A.Aghdaie and R.Momeni, Investigating Effective Factors on Development of Tourism Industry in Iran”, Asian Social Science, vol.7, 2011.

[5] A.Hünck, and S.Koot, The presentation of Bushmen in cultural tourism: tourists' images of Bushmen and the tourism provider's presentation of (Hai//om) Bushmen at Treesleeper Camp, Namibia", Routledge, Taylor and Franchis Group, University of south Africa press, 2012.

[6] N.Jaini, A.N.A.Anuar, and M.S.Daim, The Practice of Sustainable Tourism in Ecotourism Sites among Ecotourism Providers". Asian Social Science, vol.8, 2012.

[7] C.Min Chen, S.Hua Chen, and H.Tau Lee, The destination competitiveness of Kinmen's tourism industry: exploring the interrelationships between tourist perceptions, service performance, customer satisfaction and sustainable tourism", Journal of Sustainable Tourism, vol. 19, pp.247-264, 2011.

[8] R.W.Butler, Sustainable tourism: A state of the art review", Tourism Geographies, vol. 1, pp.7-25, 1999.

[9] M.Mowforth and I.Munt, "Tourism and sustainability: Development and new tourism in the Third World", London: Routledge, 2003.

[10] Bambang, Kebijakan Pembangunan Destinasi Pariwisata : Konsep dan Aplikasinya di Indonesia", Yogyakarta: Gava Media, 2013

[11] S.Wahab, Pemasaran Pariwisata", Jakarta : PT. Pradnya Paramita, 2003.

[12] LJ. Lickorish, Đeveloping Tourism Destinations : Policies and Perspectives", Longman Group, UK, 1994.

[13] R.E. Freeman, Strategic Management: A Stakeholder Approach", Boston, MA: Pitman, 1984.

[14] B. Bigelow, L. Fahey, and J.F. Mahon, A Typology of Issue Evolution", Business and Society, vol., 32, pp.18-29, 1993.

[15] J.F.Mahon and S.A.Waddock, Strategic Issues Management: An Integration of Issue life Cycle Perspectives", Business and Society, vol. 31, pp.19-32, 1992.

[16] V.J.Haukeland, Fourism Stakeholders' Perceptions of National Park Management in Norway", Journal of Sustainable Tourism, vol.19, pp.133-153, 2011.

[17] I.Mose, "Protected areas and regional development in Europe. Towards a new model for the 21 st century", Aldershot: Ashgate, 2007.

[18] T.B.Jamal and D.Getz, - Collaboration Theory and Community Tourism Planning", Annals of Tourism Research, vol. 22, pp. 186-204, 1995.

[19] P.E.Murphy, Fourism: A community approach", New York: Methuen, 1985.

[20] B. Bramwell and B. Lane, Fourism collaboration and partnerships: Politics, Practice and Sustainability", Clevedon: Channel View Publications, 2000.

[21] Sugiyono, Metode Penelitian Pendidikan : Pendekatan Kuantitatif, Kualitatif dan R dan D", Bandung : Alfabeta, 2007.

[22] B.M.Mile and Huberman, Analisis Data Kualitatif : Buku Sumber Metode-metode Baru, Universitas Indonesia, Press.Jakarta, 2007 